\title{
Perceived Stress, Stressor and the Holmes-Rahe Life Stress of Female Medical Students
}

\author{
Irma Suswati* Hendy Hendarto Margarita Maria Maramis \\ Faculty of Medicine, Kampus A Universitas Airlangga Jl. Mayjen Prof. Dr. Moestopo No. 47 Surabaya, \\ Indonesia
}

\begin{abstract}
First year female medical students have heterogeneous educational backgrounds and diferent social-economy conditions, as well as changes in instructional system may cause academic pressure that eventually leads to stress. They are also experiencing academic stressors and life stress due to their daily routines. From this situation, it is discernible that stress prevalence among them is high. This study aims to determine stress source and perceived stress, establish correlation between life stress and perceived stress, and establish correlation between life stress and stress source. This cross-sectional study was conducted to 99 female medical students. The instrument used was the stress source questionnaire, the social readjustment rating scale, and the perceived stress scale- 10 . The obtained data is analyzed using Pearson correlation and logistic regression. The findings reveal that peer competition ( $\mathrm{P}=0,014)$, loneliness $(\mathrm{P}=0,003)$, and inability to do self-adjustment $(\mathrm{P}=0,002)$ are the predictors of perceived stress. There was a significant correlation between the life stress and the perceived stress (sig 0,007 , $\mathrm{p}<0,01$ ), peer competition ( $\operatorname{sig} 0,005, \mathrm{p}<0,01$ ), and loneliness ( $\operatorname{sig} 0,024, \mathrm{p}<0,05$ ). In conclusion, peer competition, loneliness and inability to do self-adjustment are the stress predictors. The life stress with its many conflicts also influence the level of the stress. Consultation service is required to help managing and alleviating the stress such as in the forms of campus orientation program, physical or extracurricular activities, peer, family and institutional supports, creating healthy competitions, increase readiness towards changes, and stress management.
\end{abstract}

Keywords: stress, stressor, life stress, female medical students.

DOI: $10.7176 / \mathrm{JEP} / 11-27-13$

Publication date:September $30^{\text {th }} 2020$

\section{Introduction}

Stress occurs due to one's inability to adapt to internal and external pressure. Female medical students frequently experience stress. Several studies have shown that female medical students' stress levels are higher than those in other non-medical majors (Navas, 2012 \& Jafri et al., 2017). Globally, female medical students' stress prevalence is $25,6-78 \%$ (Gazzaz et al., 2018). In the Asian regions, for example, the stress prevalence in Bangladeshian state and private medical schools is 73\% (Eva et al., 2015), in Jizan University Saudi Arabia is 71,9\% (Sani et al., 2012), and in Indonesia is 48,4-61\% (Rahmayani, Liza, \& Syah, 2019) (Wahyudi, Bebasari, \& Nazriati, 2015) (Pathmanathan \& Husada, 2013). The first-year female students have the highest stress level compared to those of later years. The stress prevalence of female students is $70 \%$ higher than in the second year $60 \%$ (Ariyani, 2011) (Botelho, et al., 2017). Low-level stress helps students obtain maximum gain in life, while constant high-level stress may cause psychological and physical issues such as anxiety, depression, drug abuse and even suicide (Gazzaz, et al., 2018).

Stress is a form of interaction between an individual with the environment. It is thought to be overburdening beyond one's ability to cope and as such threatening his/ her wellbeing. There are three source of stressor for female medical students which affect their perceived stress; academic, psychosocial and environmental stressors. All three stressors have a positive correlation to perceived stress (Anuradha, Dulta, Raja, Sivaprakasam, \& Patil, 2017). Another study shows that the statistically most significant stressor are three; academic, psychosocial and health (Swaminathan, Viswanathan, Gnanadurai, Ayyavo, \& Manickam, 2016). The causes of stress for the first year female medical students are parent expectation (63\%), frequent examinations (59\%), too much subjects in the curriculum (50\%), lack of sleep (48\%), anxiety for the future (45\%), loneliness (41\%), and unsatisfaction towards the school instructional activities (35\%) (shah, Hasan, Malik, \& Sreeramareddy, 2010). The change in attitude and self-adjustment towards the new environment in the first year is burdensome. As well as the change in the learning process from high school to university, and also the different instructional activities such as in terms of length and breadth of the materials, all of them may overburden the students that they experience stress (Beall et al., 2015).

The female medical students of University of Muhammadiyah Malang (FK-UMM) have heterogeneous educational, social and economy background. In addition, the change in the instructional system may cause academic pressure that eventually leads to stress. Several studies have addressed this issue in FK-UMM, which results shows that $87,2 \%$ of the first year female medical students of FK-UMM experienced moderate level of stress. The primary stressor was academic $66.7 \%$, such as the high number of assignments, lack of time to do those assignments, and low achievement. Those are the most dominant factors causing stress (Budianta, 2016). There is 
a correlation between the perceived stress of the female medical students of FK-UMM with their premenstrual syndrome. Students with a high level of stress will show symptoms of premenstrual syndrome (Haris, 2016). It shows that students are experiencing stress and that stress may affect their academic achievements and general health. In addition to academic stressors, female medical students also experience life stress due to their daily routines (Gazzaz et al., 2018). So far, there is no study in FK-UMM which deals with the source of stress and life stressors which cause perceived stress.

According to the previous explanation, it is deemed essential to conduct a study to understand the source of stress and the life stressors which affect perceived stress. To be more specific, the aims of this study are as follows: a) to assess the perceived stress, b) to identify the stress source, c) to determine the stress source and the perceived stress, d) to assess the life stress using the Holmes-Rahe Scale, e) to establish the correlation between life stress and the perceived stress, and f) to establish the correlation between the life stress and the stress source. The results of this study are expected to inform about the source of stress and the life stress experienced by the female medical students of FK-UMM which cause perceived stress and can be used to help in planning the strategies to improve students' skills and ability to overcome stress.

\section{Methods}

This cross-sectional study was conducted at FK-UMM in 2019 using the instructional method Problem-Based Learning with Module or Block System. The population was female students of FK UMM with the sample of 104 first year female students. Prior to their agreement to join the study, the students were explained about the purpose of the study and those who approved then signed the consent form. After that, the students completed a) the stress source questionnaire from the research by Anuradha which consists of fifteen items; five items for academic stressors, five items for psychosocial stressors, and five items for environmental stressors, and b) Holmes-Rahe questionnaire (the social readjustment rating scale/SRRS) which consists of 43 items about the social or life events. Each item has its score and each item is marked as a life event that has happened in the past year. The marked item is added to generate a score in which score $<150$ shows a relatively low change in life resulting in low vulnerability towards health problems related to stress for up to 30\%. Score 150-300 shows that 50\% of health problems are caused by stress, and score $>300$ shows that $80 \%$ of health problems are caused by stress. c) the perceived stress scale questionnaire with ten items (PSS-10) by Cohen et al., in which each item is scored using the 5-point Likert Scale $(0=$ never to $4=$ very often $)$. The PSS-10 score ranges from $0-40$, with score $0-13$ considered as mild stress, score $14-26$ considered moderate stress, score 27-40 considered severe stress. The stress source questionnaire has been validated with significant value of sig $<0.05$ and its reliability has also been tested using Cronbach's alpha 0,768. As for the PSS-10 questionnaire, the validity is sig $<0,05$ and Cronbach's alpha 0,650. While the Holmes-Rahe questionnaire, its validity is sig $<0,05$ and Cronbach's alpha 0,98.

The data is then analyzed using SPSS (statistical package for social sciences) 21, the normality test was done using Shapiro wilk test and the data were normally distributed. Descriptive statistic is used to present the characteristics of the perceived stress, stress source and life stress, which are presented using percentage. Pearson Correlation is used to test the correlation between perceived stress as the dependent variable, and the stress sources; academic, psychosocial and environment as well as the life stress as the independent variable. Analysis using logistic regression is also used to determine the scores of each stressors towards the perceived stress. Odds Ratio $(\mathrm{OR})$ with trust interval of $95 \%(95 \% \mathrm{CI})$ and $p$-value $<0,05$ is considered statistically significant.

\section{Results}

The response rate of this study is $95 \%(99 / 104)$ and the average age of the female first-year student respondents is $18,56 \pm 0,83$. The average perceived stress score is $21,21 \pm 3,97$, and the median of the perceived stress was 21 . The perceived stress scores of the first year female medical students are presented in Table 1.

Table 1. The Perceived Stress Score

\begin{tabular}{|c|c|c|}
\hline Stress scores & Frequency & Percentage (\%) \\
\hline Mild (0-13) & 3 & 3,0 \\
Moderate (14-26) & 86 & 86,9 \\
Severe (27-40) & 10 & 10,1 \\
\hline Total & 99 & 100 \\
\hline
\end{tabular}

Most students (86.9\%) experience mild stress, and 10.1\% experience severe stress. The sources of stress are academic stressor, psychosocial stressor and environmental stressor, which detail is presented in Table 2. 
Table 2. Stress Sources

\begin{tabular}{|l|c|c|}
\hline \multicolumn{1}{|c|}{ Stress Sources } & $\begin{array}{c}\text { The number of respondents } \\
\text { answering 'yes' }\end{array}$ & $\begin{array}{c}\text { Percentage } \\
\text { (\%) }\end{array}$ \\
\hline Academic Stressor & 66 & 66,7 \\
- Wide array of curriculum & 85 & 85,9 \\
- High number of examinations & 42 & 42,4 \\
- Peer competition & 89 & 89,9 \\
- Scared of failing examination & 72 & 72,7 \\
- Lack of recreation time & 43 & 43,4 \\
Psychosocial Stressor & 34 & 34,3 \\
- High parental expectation & 17 & 17,2 \\
- Loneliness & 18 & 18,2 \\
- Family issues & 21 & 21,2 \\
- Financial issues & 15 & 15,2 \\
- Friendship issues & 13 & 13,1 \\
Environmental Stressor & 26 & 26,3 \\
- Commute between home and campus & 9 & 9,1 \\
- Distance between home and campus & 25 & 25,3 \\
- Food quality & & \\
- Physical home condition & - & \\
- Inability to adjust with friends & . & \\
\hline
\end{tabular}

Descriptively, most stress sources are academic stressors; scared of failing examinations is $89.9 \%$, the high number of examinations $85.9 \%$, lack of recreation time $72.7 \%$, and the wide array of curriculum $66.7 \%$. Next, the logistic regression results between stress source and the perceived stress are presented in Table 3 .

Table 3. The Logistic Regression Analysis between Stress Source and The Perceived Stress

\begin{tabular}{|l|c|c|}
\hline \multicolumn{1}{|c|}{ Stress Sources } & OR (95\%CI) & P value \\
\hline Peer competition & 6.471 & .014 \\
Loneliness & 9.692 & .003 \\
Inability to adjust with friends & 9.204 & .002 \\
\hline
\end{tabular}

The analysis results show that peer competition $(\mathrm{P}=0,014)$, loneliness $(\mathrm{P}=0,003)$, and inability to adjust with friends $(\mathrm{P}=0,002)$ are stress sources which predict stress among female students, while other sources are not predictors of stress among female medical students. Next, the Pearson Correlation results show that there is positive and significant correlation between peer competition and perceived stress ( $\operatorname{sig} 0,004, p<0,01)$, loneliness and perceived stress ( $\operatorname{sig} 0,006, \mathrm{p}<0,01$ ), and the inability to adjust with friends and perceived stress (sig $0,001, \mathrm{p}<0,01)$. The life stress of students are presented in Table 4 .

Table 4. The Life Stress Scores based on The Social Readjustment Rating Scale

\begin{tabular}{|c|c|c|}
\hline Holmes Rahe Score & Frequency & Percentage (\%) \\
\hline Mild $(<150)$ & 26 & 26,3 \\
Moderate $(150-300)$ & 58 & 58,6 \\
Wevere $(>300)$ & 15 & 15,2 \\
\hline Total & 99 & 100 \\
\hline
\end{tabular}

The life stress is mostly $58,6 \%$ in moderate category, and $26,3 \%$ in mild category. The Pearson Correlation result between life stress and percieved stress shows significant correlation between life stress and perceived stress (sig $0,007, \mathrm{p}<0,01)$. The Pearson Correlation analysis between the life stress and the stress sources also show significant correlations; between life stress and peer competition ( $\operatorname{sig} 0,005, \mathrm{p}<0,01$ ), and between life stress and loneliness ( $\operatorname{sig} 0,024, p<0,05$ ), while between life stress and the inability to adjust with friends shows no correlation $(\mathrm{p}>0,05)$.

\section{Discussion}

The findings of the current study show that the first year female students' perceived stress score was mostly moderate $(86,9 \%)$. It is similar to the findings of the previous study with the highest stress prevalence of $82,6 \%$ for the first year female students (Rafique et al., 2019). This high stress level in the first year female students are due to the all female sample of this study, which, according to several studies show higher stress level than the male counterparts (Sohail, 2013) (Anuradha et al., 2017) (Rafique et al., 2019). In addition, the first year students have a higher stress level, which is in line with the previous study that conclude that the first year students have the highest stress level which decreases in the next and following years (Abdulghani, Alkanhal, Mahmoud, Pannamperuma, \& Alfaris, 2011). The stress among the medical students is dynamic as it varies according to the curriculum (Garg, Agarwal, \& Dalal, 2017). 
The academic, psychosocial and environmental stress sources that influence the students' perceived stress are loneliness (OR 9,69, $\mathrm{P}=0,003$ ), inability to adjust (OR 9,20, $\mathrm{P}=0,002)$, ad peer competition (OR 6,47, $\mathrm{P}=0,014$ ). All of the three factors are predictors of stress for the first year female medical students of FK-UMM. The results of the current study, compared to previous studies, found one of the stress sources that influence the students' perceived stress is loneliness. The difference occurs due to the difference in the sample used as the previous study used medical students from the first to the last year of study (Anuradha, Dulta, Raja, Sivaprakasam, \& Patil, 2017), while this study only covers the first-year students. They are very vulnerable to stress as they are undergoing the change and transition into the new environment (Salam, Yousuf, Abu Bakar, \& Haque, 2013) (Hill, Goicochea, \& Merio, 2018). The beginning of one study means entering a new life full of pressure and demands (Bergmann, Muth, \& Loerbroks, 2019). Loneliness is one factor becoming the predictor of perceived stress (OR 9,69, $\mathrm{P}=0,003)$. It happens due to social or emotional lonesomeness. When students commence a new study, they may move to a new place, face a change in family relation matters, be alone in a new unfamiliar environment, not knowing anyone. In addition, the high proportion of independent learning and lack of physical activities also became the reasons why the prevalence of loneliness was high (Diehl, Jansen, Ishchanova, \& Hilger-Kolb, 2018). Finally, the firstyear students' inability to adjust also became one of the predictors of perceived stress (OR 9,20, $\mathrm{P}=0,002)$. It is in line with a Bahrain-based study which also found that first-year students with age range of 18-20 faced a high risk of adaptation failure due to the sudden change in their life caused by the new challenge (Alnakhli, et al., 2018). Peer competition may cause someone to climb to a higher level, but at the same time it can also be the cause of stress (Hill, Goicochea, \& Merio, 2018). Competition is closely related to depression and anxiety among female students, perceived competition in the academic environment increase anxiety level up to $70 \%$, and depression up to $40 \%$. In addition, high competition rate also positively correlate with depression and anxiety. Female students who think that their class is highly competitive have a higher anxiety and depression probability. Conversely, those who think that their class is less competitive also show lower anxiety and depression probability (Posselt \& Lipson, 2016).

Life stress based on SRRS in the current study is mostly in the moderate level - 58,6\% (score $150-300$ ), this means that the life event happening the past year caused vulnerability towards health problems due to stress for about $50 \%$. Previous studies also show that female medical students' stress levels were moderate - 71,67\% (score $150-300)$, which suggests the heterogeneity of the stress sources and the high-stress vulnerability of medical students. Such a high level of stress is related to the daily life stressors added with additional assignments, lack of leisure time and the wide array of materials that have to be learned, and the high number of examinations (Sohail, 2013). The current study also indicates that the life event in the past year has a significant correlation with the perceived stress ( $\operatorname{sig} 0,007, p<0,01)$ and stress sources such as peer competition ( $\operatorname{sig} 0,005, p<0,01)$, and loneliness ( $\operatorname{sig} 0,024, \mathrm{p}<0,05)$. However, there is no significant correlation with students' inability to adjust with friends $(p>0,05)$. It shows that life stress characterized by pressure, family conflicts and social problems significantly impacts one's stress level (Hassanzadeh, et al., 2017).

\section{Conclusion}

The level of perceived stress is high among the female first-year medical students, and the stress sources acting as predictors are loneliness, peer competition, and inability to do self-adjustment. In addition, the life stress characterized by conflicts also influenced the student stress level. It is because first-year students are in the middle of transition time into the new environment. Therefore a consultation service is necessary to help to alleviate the stress level. Also, it is important to offer campus orientation programs, physical and extracurricular activities, friends, family and institutional supports, and creating healthy competition level which helps students to adapt to change and to manage stress.

\section{Acknowledgment}

Our special thanks to University of Muhammadiyah Malang for funding and supporting this research.

\section{References}

Abdulghani, H., Alkanhal, A., Mahmoud, E., Pannamperuma, G., \& Alfaris, E. (2011), "Stress and its effects on medical students: a cross-sectional study at a college of medicine in Saudi Arabia", J Health, Population and Nutrition 29(5), 516-522.

Alnakhli, B., Al-Mahrezi, A., Al-Radhi, F., Mohammad, A., Bohulaygah, A., Alzoori, F., ... Al-Hurayis, M. (2018), "Adjustment disorder among medical students in Arabian Gulf University Bahrain, a cross-sectional, descriptive study", International Journal of Advanced Research (IJAR) 6(2), 442-446.

Anuradha, R., Dulta, R., Raja, J., Sivaprakasam, P., \& Patil, A. (2017), "Stress and Stressors among Medical Undergraduate Students: A Cross-sectional Study in a Private Medical College in Tamil Nadu", Indian Journal of Community Medicine 42(4), 1-4.

Ariyani, M. (2011), "Perbedaan Tingkat Stres Mahasiswa Kedokteran Pada Tahun Pertama dan Tahun Ketiga 
Fakultas Kedokteran Universitas Muhammadiyah Malang”, Undergraduate Thesis, Malang: UMM Institutional Repository, htttp://eprints.umm.ac.id/31682/.

Beall, J., DeHart, R., Riggs, R., \& Hensley, J. (2015), "Perceived Stress, Stressors, and Coping Mechanisms among Doctor of Pharmacy Students", Pharmacy, 344-354.

Bergmann, C., Muth, T., \& Loerbroks, A. (2019), "Medical students' perceptions of stress due to academic studies and its interrelationships with other domains of life: a qualitative study", Medical education online vol 24, 1-10.

Botelho, F., Bergamo, I., Oliveira, M., Trevizan, F., Pacca, F., Fucuta, P., \& Cury, P. (2017), "Stress Level Assessment of Medical School Program and correlations between Learning Styles and Teaching Methodologies", Amee MedEdPublish, 1-11.

Budianta, R. (2016), "Faktor Penyebab Stres yang Dominan pada Mahasiswa Tahun Pertama Fakultas Kedokteran Universitas Muhammadiyah Malang", Undergraduate Thesis, Malang: UMM Institutional Repository, http://eprint.umm.ac.id/34703.

Diehl, K., Jansen, C., Ishchanova, K., \& Hilger-Kolb, J. (2018), "Loneliness at universities: determinants of emotional and social loneliness among students", International journal of environmental research and public health 15,1865, 1-14.

Eva, E., Islam, M., Mosaddek, A., Rahman, M., Rozario, R., \& Iftekhar, A. (2015), "Prevalence of stress among medical students; a comparative study between public and private medical schools in Bangladesh", Bio Med Central 372(8), 1-7.

Garg, K., Agarwal, M., \& Dalal, P. (2017), "Stress among medical students: a cross-sectional study form a north Indian Medical University”, Journal of the college of physicians and surgeons Pakistan vol 23(1), 67-71.

Gazzaz, Z., Baig, M., Al-Alhendi, B., Al-Suliman, M., Al-Alhendi, A., Al-Grad, M., \& QUrayshah, M. (2018), "Perceived stress, reasons for and sources of stress among medical students at Rabigh Medical College, King Abdulaziz University, Jeddah, Saudi Arabia”, MBC Medical Education 18:19, 1-9.

Haris, A. (2016), "Hubungan antara Stres Terhadap Premenstrual Syndrome (PMS) pada Mahasiswa Tahun Pertama di Fakultas Kedokteran Universitas Muhammadiyah Malang”, Undergraduate Thesis, Malang: UMM Institutional Repository; http://eprints.umm.ac.id/34705.

Hassanzadeh, A., Heidari, Z., Feizi, A., Keshteli, A., Roohafza, H., Afshar, H., \& Adibi, P. (2017), “Association of stressful live events with psychological problems: a large-scale community-based study using grouped outcomes latent factor regression with latent predictors", Hindawi Computational and Mathematical Methods in Medicine volume 2017, 1-13.

Hill, M., Goicochea, S., \& Merio, L. (2018), "In their own words: stressors facing medical students in the millennia generation", Medical education online vol 23, 1530558, 1-10.

Jafri, S., Zaidi, E., Aamir, I., Aziz, H., Imaduddin, \& Shah, M. (2017), "Stress level comparison of medical and non-medical students: a cross sectional study done at various professional colleges in Karachi, Pakistan", iMedPub Journals Acta psychopathologica ISSN 2469-6676. Vol 3 no 2:8, 1-6.

Navas, S. (2012), "Stress among medical students", Kerala medical journal vol $\mathbf{V}$ issue 2, 34-37.

Pathmanathan, V., \& Husada, M. (2013), "Gambaran Tingkat Stres pada Mahasiswa Kedokteran Universitas Sumatera Utara Semester Ganjil Tahun Akademik 2012/2013”, E-Journal FKUSU Vol 1 No 1, 1-4.

Posselt, J., \& Lipson, S. (2016), "Competition, anxiety, and depression in the college classroom: variations by student identity and field of study", Journal of college student development vol 57 no 8, 973-989.

Rafique, N., Al-Asoom, L., Latif, R., Al-Sunni, A., \& Wasi, S. (2019), "Comparing levels of psychological stress and its inducing factors among medical students”, Journal of Taibah University Medical Sciences 14(6), 488494.

Rahmayani, D., Liza, R., \& Syah, N. (2019), “Gambaran Tingkat Stres Berdasarkan Stressor pada Mahasiswa Kedokteran Tahun Pertama Program Studi Profesi Dokter Fakultas Kedokteran Universitas Andalas Angkatan 2017”, Jurnal Kesehatan Andalas, 8(1), 103-111.

Salam, A., Yousuf, S., Abu Bakar, S., \& Haque, M. (2013), "Stress among medical students in Malaysia: a systematic review of literature", International Medical Journal Vol 20 no 6, 649-655.

Sani, M., Mahfouz, M., Bani, I., Alsomily, A., Alagi, D., \& Alsomily, N. (2012), "Prevalence of stress among medical students in Jizan University, Kingdom of Saudi Arabia", Gulf Med J (1), 19-25.

Shah, M., Hasan, S., Malik, S., \& Sreeramareddy, C. (2010), "Perceived Stress, Sources and Severity of Stress among medical undergraduates in a Pakistani Medical School", BMC Medical education, 1-8.

Sohail, N. (2013), "Stress and academic performance among medical students", Journal of the college of Physicians and Surgeons Pakistan. Vol. 23(1), 67-71.

Swaminathan, A., Viswanathan, S., Gnanadurai, T., Ayyavo, S., \& Manickam, T. (2016), "Perceived Stress and Sources of Stress among First-year Medical Undergraduate Students in a private Medical College -Tamil Nadu", National Journal of Physiology, Pharmacy and Pharmacology, volume 6 issue 1, 9-14.

Wahyudi, R., Bebasari, E., \& Nazriati. (2015), "Gambaran Tingkat Stres pada Mahasiswa Fakultas Kedokteran Universitas Riau Tahun Pertama”, JIK, jilid 9 nomor 2, 107-113. 